৩コメント

\title{
麂應義熟大学経济学部 木村福成
}

原教授の論文は, 急速なグローバリゼーションが進行する中で, 日本が対応 を迫られている 3 つの挑戦，すなわち（i ）アングロ・アメリカン・スタンダ ードの浸透，（ii）地域経済統合の拡大・深化，（iii）民主化と市場経済化の関 わりについての議論の出発点を提示している。本論文は, 同じ筆者による『地 球化時代の日本経済』(文眞堂，2001年）の内容を大幅に更新したものとなっ ており，スケールの大きな現代日本経済論を展開している。

（ｉ）のアングロ・アメリカン・スタンダードについては，「システム」をど のように機能的に分解し，国際間で収束すべき部分としなくてもよい部分とを 区別するかが課題となる。原教授は，各国経済を結合するのに最低限必要とさ れる「ミニマム・スタンダード」を設定すべき，と主張する。経済システムは 各国固有の社会・文化と不可分な形で存在しており，しかも相互依存的な諸制 度によって支えられているのであるから，受容国がスタンダードの受け入れに 当たって注意深い仕分けを行扮うとするのは当然の対応である。

問題は，ミニマム・スタンダードをどのような基準に基づいて設定するかに ある。現実にはケース・バイ・ケースの対応とならざるを得ないとしても，何 らかの客観的・学術的なアプローチを提示しておくことは, 推進派・ 反対派双 方からの政治経済的圧力によって歪められた結論を回避するために不可欠であ る。

この問題については評者も包括的な解答を有しているわけではないが，ここ では考慮されるべき 3 つの要素を列挙しておきたい。第 1 に, 特にWTOの政 策規律に関しては，無差別原則（non-discrimination principle）と制度の調和 ・ 収束（institutional harmonization and convergence）とを区別し，前者のみを大原 則と解釈するということを，はっきりと確認しておく必要がある。そもそも， 国際通商政策規律はもっぱら効率性を基準として組み立てられているのに対し， 国内政策は所得分配への配慮等を含む複雑な目的関数に基づいて策定・施行さ 
れる。まず行うべきことは，国境措置に関する無差別原則の延長上で考えうる ものとそうでないものとを峻別することである。

第 2 に，コらに進んで制度の調和・収束の適否を検討するに当たっては，そ もそも外来のスタンダード以外の選択肢が存在するのかどうかを，冷静に検討 すべきである。「日本的経済システム」なるもののどの部分が今後も有効であ りえるのか，世界大のスタンダードと相容れない部分はどこなのかを，明確に しなければならない。

第 3 に，調和・収束のコストとベネフィットを包括的に評価する必要がある。 コストには，経済・社会構造との不適合等から生ずるコストのみならず，調 和・収束過程での調整費用を含めて考えるべきであろう。一方，ベネフィット については，効率性，技術的優位性，ネットワーク外部性などから生ずる利益. を評価しなければならない。

我々は，少なくともこれら 3 つの観点からの検討を行いながら，ミニマム・ スタンダードを設定していくべきである。

次に，(ii）の地域経済統合に関連して，原教授は，求めるべき世界経済シ ステムとして三極（アメリカ，ヨーロッパ，東アジア）・層（世界，地域， 国）構造を提示している。「地域」がシステムの1つの拠り所となりうるとの 指摘は，卓見である。日本に扮ける自由貿易協定（FTA）論議ではしばしば忘 れられている点であり，日星FTAからさらに進んで日韓FTA，東アジアFTA を検討していく際には，是非とも明示的に議論されるべき問題である。

三極・三層構造の実現可能性をめぐっては，3極目の「東アジア」，2 層目 の「地域」という要素が成立しうるかどうかが鍵となるのであろう。東アジア が共有しうる制度・システムの萌芽は本当に存在するのか, 地域で共有する制 度・システムの構築過程で日本が果たしうる役割は何なのかについて, さらに 具体的に議論を重ねていく必要がある。また，WTO整合性や日本の歴史的立 場，通商政策と他分野の政策とのリンクなどに関連して，東アジアの経済統合 をどのようにデザインするかについても，より詳細な検討が必要となってくる 
であろう。

（iii）の民主化と市場経済化の関係について，原教授は，民主主義的市場経 济への移行の必要性・必然性を踏まえながらも，そこに向かう経路は複数存在 すると主張している。民主主義をめぐる問題を体系的に論ずることは評者の能 力を大きく超えるものであるが，グローバリゼーション進行下でその経路に変 化が生じてくることは指摘の通りだろう。これに関連して，数年来世界銀行が 取り組んでいる包括的開発枠組み (CDF) や貧困削減戦略ペーパー（PRSP） では発展途上国側の「参加」がキーワードの1つとなっており，それが民主主 義についてどのような新たな地平を切り開いていくことになるのかについても， 注目していきたい。

以上のように，原論文は，今後の世界経済システムを考察していく上での有 用な出発点を提供しているものとして，高く評価されるものである。 